\title{
PREFERENSI HABITAT BINTANG LAUT (Asteroidea) DI PADANG LAMUN PERAIRAN DESA LANGARA BAJO, KONAWE KEPULAUAN
}

\author{
Habitat Preference Of Sea Star (Asteroidea) In Seagrass Beds in The \\ Langara Bajo Waters Konawe Islands
}

\author{
Nur Alfatmadina ${ }^{1}$ Ira $^{2}$, La Ode Muhammad Yasir Haya ${ }^{3}$ \\ 1,2,3 Jurusan Ilmu Kelautan, Fakultas Perikanan dan Ilmu Kelautan, Universitas Halu Oleo. \\ Jl. H.E.A Mokodompit Kampus Hijau Bumi Tridharma Anduonohu Kendari 93232 \\ ${ }^{1}$ Email: alfatmadinanur96@gmail.com
}

\begin{abstract}
Abstrak
Bintang laut merupakan salah satu kelompok hewan dalam Filum Echinodermata yang ditemukan hampir di semua perairan di Indonesia. Bintang laut biasanya ditemukan pada ekosistem yang ada di pesisir, termasuk ekosistem lamun. Lamun merupakan tempat bagi sebagian besar organisme khususnya bintang laut untuk mencari makan, berpijah dan tempat berlindung dari predator. Perbedaan pemilihan habitat pada organisme biasanya disebabkan oleh faktor internal (genetik) dan eksternal (kemampuan adaptasi dengan lingkungannya). Tujuan dari penelitian ini adalah untuk mengetahui jenis dan kepadatan bintang laut dan lamun di Perairan Desa Langara Bajo berdasarkan jenis substratnya. Penelitian ini dilaksanakan pada bulan April-Juni 2018 di perairan Desa Langara Bajo Konawe Kepulauan. Pengambilan data dilakukan dengan menggunakan metode transek kuadrat sebanyak tiga kali pengulangan pada sertiap stasiun pengamatan.Penelitian ini menemukan tiga jenis bintang laut, yaitu Protoreaster nodosus, Linckia laevigata dan Archaster typicus dengan kepadatan berkisar 1.63-2 ind $/ \mathrm{m}^{2}$. Jenis lamun yang ditemukan berasal dari jenis Enhalus acoroides dengan kepadatan berkisar 189.7-589.7 tegakan $/ \mathrm{m}^{2}$. Jenis bintang laut P.nodosus banyak ditemukan di stasiun yang kerapatan lamunnya tinggi denan substrat berpasir, sedangkan jenis $A$. typicus ditemukan pada stasiun yang kerapatan lamunnya jarang dengan substrat berpasir.
\end{abstract}

Kata Kunci: Bintang Laut, Lamun, Kepadatan, Substrat, Konawe Kepulauan

\begin{abstract}
Absrtact
Sea stars are one of the groups of animals in Echinoderms Phylum found in almost all Indonesian waters. Sea stars are usually found in coastal ecosystems, including seagrass ecosystem. Seagrasses is a place for most organisms, especially sea stars, to forage, spawn and shelter from predators. Differences in habitat selection in organisms are usually caused by internal (genetic) and external (adaptability to the environment). The purpose of this study was to determine the species and density of sea star and seagrasses in the waters of Langara Bajo based on the type of substrate. This research was conducted in April-June 2018 in the Langara Bajo Waters, Konawe Islands. Data retrieval was done by using the transect squared method as many as three repetitions at each observation station. This study found three species of sea star, namely Protoreaster nodosus, Linckia laevigata and Archaster typicus with density ranged from $1.63-2 \mathrm{ind} / \mathrm{m}^{2}$. Seagrass species found was Enhalus acoroides species with density ranged from 189.7-589.7 stands / $\mathrm{m}^{2}$. The sea star species P.nodosus was found in stations with high seagrass density with sand substrates, whereas species A. typicus was found in stations with rare seagrass densities with sand substrates.
\end{abstract}

Keywords: starfish, seagrass, density, substrate, Konawe Islands

\section{Pendahuluan}

Indonesia merupakan negara

kepulauan terluas di dunia yang memiliki sekitar 13 ribu gugusan pulau, serta memiliki letak yang strategis dan garis pantai terpanjang sehingga merupakan tempat hidup bagi berbagai biota laut. Salah satu biota yang hidup pada perairan tropis dan subtropis adalah bintang laut (Asteroidea).

Pengetahuan tentang biota laut di suatu perairan sangatlah penting karena menyangkut dengan cara pengelolaan dan pemanfaatannya, yang kemudian diketahui populasi yang dominan pada suatu perairan. 
Perairan yang memiliki keanekaragaman biota laut yang tinggi dapat dimanfaatkan oleh manusia baik sebagai bahan makanan, hiasan maupun komoditas untuk di ekspor salah satunya hewan benthos (Bintang laut) (Yumima dan Jaida, 2013).

Bintang laut merupakan anggota kelompok Echinodermata, mereka merupakan salah satu biota laut yang berasosiasi kuat dengan padang lamun dan berperan dalam siklus rantai makanan di ekosistem tersebut. Tingginya tutupan vegetasi lamun di perairan memungkinkan kehadiran berbagai biota yang berasosiasi dengan padang lamun termasuk bintang laut untuk mencari makan, tempat hidup, memijah dan tempat berlindung untuk menghindari predator (Supono dan Arbi, 2010).

Distribusi bintang laut di perairan sangat tergantung pada faktor- faktor lingkungan diantaranya terkait dengan substrat dan ketersediaan makanan. Keberadaan bintang laut di perairan dapat ditemukan hingga kedalaman 10 meter dan biasanya hidup secara berkelompok sesuai penyebarannya. Kerusakan ekosistem lamun dapat menyebabkan keberadaan bintang laut di perairan menjadi terancam dan populasinya berkurang (Rompis dkk., 2013).

Perbedaan pemilihan habitat oleh organisme dipengaruhi oleh beberapa faktor (internal dan eksternal). Menurut Lee dan Shin (2013), beberapa faktor yang mempengaruhi keberadaan organisme adalah faktor genetik, dan tingkat adaptasi terhadap habitat lainnya. Selain itu bintang laut membutuhkan habitat yang mampu menyediakan makanan serta tempat yang aman digunakan untuk berlindung larva dari predator yang dapat memangsanya.

Menurut Puspitasari dkk., (2012), dalam penelitiannya dijelaskan bahwa sebagian besar bintang laut yang diteliti dari genus Linckia dan Nardoa mampu bertahan hidup dari mukus yang dihasilkan oleh hewan karang dan spons. Genus Acanthaster ditemukan di daerah berpasir dan genus Protoreaster dan Echinaster ditemukan di daerah padang lamun. Keberadaan organisme tersebut pada ekosistem merupakan suatu hal yang sangat penting karena adanya hubungan timbal balik yang berpengaruh terhadap habitatnya (Gaffar dkk., 2015).
Pulau Wawonii merupakan sebuah hamparan territorial tersendiri yang terletak digugusan perairan laut Banda dan merupakan bagian integral dari wilayah administratif Kabupaten Konawe. Pulau ini memiliki keanekaragaman hayati laut yang berlimpah terutama pada ekosistem pesisirnya yang salah satunya adalah ekosistem lamun dimana banyak organisme yang berasosisasi di lamun salah satunya bintang laut. Organisme tersebut memanfaatkan lamun sebagai tempat mencari makan, memijah maupun menjadikannya sebagai daerah asuhan dan lain lain. Berdasarkan latar belakang diatas, maka perlunya dilakukan penelitian mengenai preferensi habitat bintang laut pada derah padang lamun.

\section{Bahan dan Metode}

Penelitian ini dilaksanakan pada Bulan April-Juni 2018 di Perairan Wawonii, Kabupaten Konawe Kepulauan yang meliputi; studi literatur, survey awal/observasi, pengambilan data di lapangan, pengolahan data, analisis data dan penyusunan hasil penelitian. Analisis kualitas air dan tekstur substrat dilakukan di Laboratorium Pengujian Bahan dan Konstruksi, Fakultas Teknik, Universitas Halu Oleo, Kendari. Peta lokasi penelitian di Perairan Desa Langara Bajo , Konawe Kepulauan dapat di lihat pada Gambar 1.

Prosedur penelitian meliputi; survey pendahuluan, penentuan stasiun penelitian, pengambilan data lamun dan Bintang laut, pengukuran kualitas perairan dan pengambilan sampel sedimen, dan analisis laboratorium.

Tahap survey pendahuluan dilakukan untuk mengetahui kondisi lokasi penelitian, penentuan titik stasiun dalam pengambilan sampel dan persiapan peralatan yang akan digunakan di lapangan. Berdasarkan survey pendahuluan yang telah dilakukan, lokasi penentuan stasiun penelitian dilakukan berdasarkan kondisi dan keberadaan lamun yaitu; Stasiun I, terletak dibagian Barat desa Langara Bajo, berada pada titik koordinat

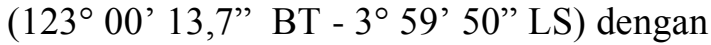
kondisi lamun yang lebih padat dibandingkan dengan stasiun II dan stasiun III. Stasiun II, terletak dibagaian Barat desa Langara Bajo namun dekat dengan hutan mangrove, berada pada titik koordinat $\left(123^{\circ}\right.$ 
00' 1,69” BT - 3० 59' 46,5” LS) dengan kondisi lamun lebih jarang dibandingkan dengan stasiun I. Stasiun III, terletak dibagian Barat desa Langara, berada pada titik koordinat $\left(122^{\circ} 59^{\prime} 43,8^{\prime \prime} \mathrm{BT}-4^{\circ} 00^{\prime}\right.$ $44,3^{\prime \prime}$ LS) dengan kondisi lamun yang lebih jarang dibandingkan stasiun I dan II.

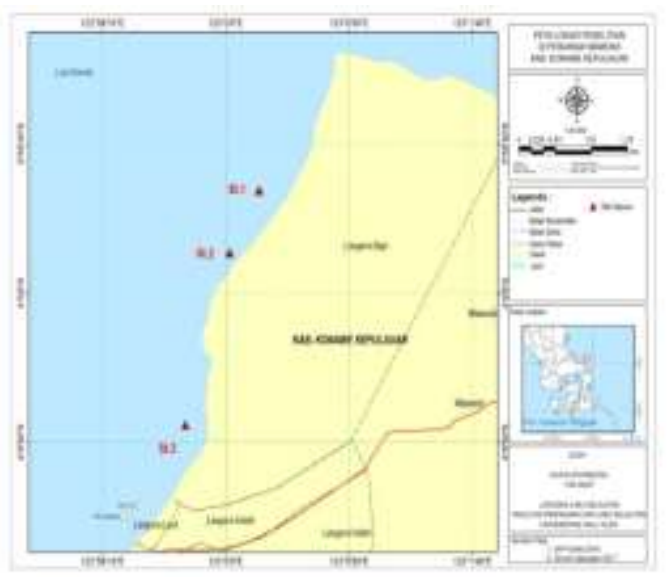

Gambar 1. Peta Lokasi Penelitian Perairan Wawonii, Konawe Kepulauan.

Pengambilan data populasi bintang laut dilakukan dengan menggunakan metode transek kuadrat. Transek garis dengan panjang 100 meter yang dibentangkan tegak lurus terhadap garis pantai, yang dilakukan pada saat air laut surut atau menjelang surut terendah. Mulai dari titik nol diletakkan transek kuadrat $1 \times 1$ meter dengan jarak 10 meter, sedangkan jarak untuk tiap transek garis adalah 20 meter dengan 3 kali pengulangan (Khouw, 2008).
Pengukuran kualitas perairan dilakukan secara insitu yang bertujuan untuk mengetahui kondisi perairan habitat bintang laut yang meliputi; pengukuran suhu, salinitas, kecepatan arus, $\mathrm{pH}$, kecerahan, kedalaman perairan serta uji tekstur substrat dilakukan di laboratorium.

Berdasarkan data parameter kualitas perairan, jenis Bintang laut dan jenis lamun, data yang diperoleh dianalisis secara deskriptif kuantitatif yaitu memberikan gambaran dalam bentuk tabel dan grafik. Hal ini dimaksudkan agar data yang diperoleh lebih mudah dibaca dan diinterprestasikan untuk mengetahui kepadatan Bintang laut dan lamun.

Kepadatan adalah jumlah individu persatuan luas. Kepadatan masing-masing jenis pada setiap stasiun dihitung dengan menggunakan rumus Odum (1993) :

$\mathrm{D}_{\mathrm{i}}=\frac{n_{i}}{\mathrm{~A}}$

dimana : $D_{i}=$ Kepadatan Bintang laut $\left(\mathrm{ind} / \mathrm{m}^{2}\right), \quad \mathrm{n}_{\mathrm{i}}=$ Jumlah total individu (individu), $\mathrm{A}=$ Luas daerah yang disampling $\left(\mathrm{m}^{2}\right)$

Kepadatan lamun dihitung dengan menggunakan rumus yang diekmukakan oleh (Soegianto, 1994) yaitu sebagai berikut :

$\mathrm{D}=\frac{\mathrm{N}}{\mathrm{A}}$ dimana :

$\mathrm{D}=$ Kepadatan jenis ke-i (tegakan $\left./ \mathrm{m}^{2}\right), \mathrm{N}=$ Jumlah total tegakan jenis ke-i, $\mathrm{A}=$ Luas area plot pengamatan $\left(\mathrm{m}^{2}\right)$

Analisis ukuran butir substrat dilakukan dengan metode saringan bertingkat menggunakan skala Wenworth (Hutabarat dan Evans, 1985).

Tabel 1. Skala Wenworth untuk mengkalasifikasikan partikel partikel sedimen (Hutabarat dan Evans, 1985).

\begin{tabular}{cc}
\hline Ukuran $(\mathbf{m m})$ & Keterangan \\
\hline$>256$ & Kerakal \\
$2-256$ & Kerikil \\
$1-2$ & Pasir sangat kasar \\
$0.5-1$ & Pasir kasar \\
$0.25-0.5$ & Pasir agak kasar \\
$0.125-0.25$ & Pasir halus \\
$0.0625-0.125$ & Pasir sangat halus \\
$0.0039-0.00625$ & Lanau \\
$<0.0039$ & Lempung \\
\hline
\end{tabular}




\section{Hasil dan Pembahasan}

Jenis bintang laut yang ditemukan pada lokasi penelitian berjumlah 3 jenis, yaitu Protoreaster nodosus, Linckia laevigata dan Archaster typicus. Jenis yang paling banyak ditemukan adalah dari jenis P.nodosus dan yang paling sedikit ditemukan adalah jenis L.laevigata (Tabel 3). Hal ini dikarenakan penelitian ini hanya dilakukan pada daerah padang lamun yang pada dasarnya hanya sebagian kecil jenis bintang laut yang dapat berasosiasi dengan lamun.

Berdasarkan penelitian yang dilakukan di Perairan Desa Langara Bajo, setiap stasiun memiliki kepadatan jenis yang bebeda-beda. Kepadatan tertinggi berada pada stasiun III yaitu $2 \mathrm{ind} / \mathrm{m}^{2}$ dengan jumlah individu 60 spesies, yang diikuti oleh stasiun I diperoleh 1,63 ind $/ \mathrm{m}^{2}$ dengan jumlah individu 49 spesies kemudian dilanjutkan dengan stasiun II yaitu diperoleh $1,07 \mathrm{ind} / \mathrm{m}^{2}$ dengan jumlah individu 32 spesies.

Bintang laut jenis P.nodosus ditemukan melimpah pada semua stasiun penelitian. Hal ini dikarenakan pada lokasi penelitian adalah ekosistem padang lamun yang merupakan salah satu tempat mencari makan bagi bintang laut jenis ini yang mana makanannya berupa mikrofauna serta menyukai substrat pasir. Hal ini sesuai pernyataan Moosleitner (2004) bahwa bintang laut P.nodosus merupakan bintang laut yang berukuran besar yang diketahui menyukai daerah padang lamun dan substrat yang berpasir. Sedangkan jenis A.typicus ditemukan secara berkelompokkelompok kecil yang menempati daerah perairan dangkal dengan substrat berpasir. Keberadaannya pada lokasi penelitian karena sebagian besar lokasi penelitian adalah tipe substrat berpasir. Hal ini sesuai pernyataan
Sloan (1981) bahwa bintang laut jenis A.typicus dan A. angukatus ditemukan pada daerah berpasir.

Selain kedua jenis bintang laut tersebut, pada stasiun III ditemukan bintang laut jenis L.laevigata yang umumnya hidup pada ekosistem terumbu karang. Ditemukannya jenis L.laevigata pada daerah padang lamun, diduga karena adanya gangguan dari kondisi lingkungan yang tidak memungkinkan organisme ini hidup pada terumbu karang. Selain hidup pada daerah terumbu karang, bintang laut jenis ini juga dapat hidup di terumbu karang yang ditumbuhi alga karena merupakan makanan baginya. Hal ini sesuai dengan pernyataan Zamani (2015) bahwa bintang laut L.laevigata hidup pada daerah yang banyak ditumbuhi alga dan mengkonsumsi alga sebagai makanannya.

Berdasarkan hasil penelitian, parameter lingkungan di Perairan Desa Lagara Bajo masih memungkinkan untuk perkembangbiakan bintang laut, diantaranya suhu, salinitas $\mathrm{pH}$ dan substrat. Suhu merupakan salah satu faktor yang mempengaruhi keberlangsungan hidup organisme di lautan. Suhu mempengaruhi proses metabolisme pada organisme, selain itu juga berperan dalam proses fisiologi dan respirasi mahluk hidup (Marsh et al, 1986). Pengamatan yang dilakukan pada Perairan Desa Langara Bajo diperoleh suhu $28-29{ }^{\circ} \mathrm{C}$. Suhu mempengaruhi hewan benthos maupun lamun dan organisme lainnya yang hidup berasosiasi pada lingkungan perairan tersebut. Hal ini sesuai pernyataan Zimmerman $d k k$., (1987), bahwa kisaran suhu optimal untuk pertumbuhan lamun dan organisme benthos berkisar antara $29-30{ }^{\circ} \mathrm{C}$.

Tabel 2. Jenis dan jumlah bintang laut yang ditemukan pada Perairan Desa Langara Bajo, Konawe Kepulauan

\begin{tabular}{clccc}
\hline No. & Jenis Bintang Laut & \multicolumn{3}{c}{ Jumlah } \\
\cline { 3 - 5 } & & Stasiun I & Stasiun II & Stasiun III \\
\hline 1 & Protoreaster nodosus & 49 & 32 & 47 \\
2 & Linckia laevigata & 0 & 0 & 1 \\
3 & Archaster typicus & 0 & 0 & 12 \\
\hline
\end{tabular}

Tabel 3. Kepadatan jenis bintang laut di Perairan Desa Langara Bajo, Konawe Kepulauan

\begin{tabular}{cc}
\hline Stasiun & Kepadatan Bintang laut $\left(\mathbf{I n d} / \mathbf{m}^{2}\right)$ \\
\hline I & 1,63 \\
II & 1,07 \\
III & 2 \\
\hline
\end{tabular}


Tabel 4. Hubungan Kepadatan lamun dengan Bintang Laut di Perairan Desa Langara Bajo, Konawe Kepulauan

\begin{tabular}{ccc}
\hline Stasiun & Kepadatan Lamun $\left(\right.$ Tegakan $\left./ \mathbf{m}^{\mathbf{2}}\right)$ & Kepadatan Bintang Laut $\left(\mathbf{I n d} / \mathbf{m}^{\mathbf{2}}\right)$ \\
\hline I & 589.66 & 1,63 \\
II & 340.33 & 1,07 \\
III & 189.66 & 2 \\
\hline
\end{tabular}

Tabel 5. Hasil pengukuran kualitas Perairan di desa Langara Bajo, Konawe Kepulauan

\begin{tabular}{ccccccc}
\hline Stasiun & $\begin{array}{c}\text { Suhu } \\
\left({ }^{\mathbf{C}} \mathbf{C}\right)\end{array}$ & $\begin{array}{c}\text { Kecepatan } \\
\text { Arus }(\mathbf{m} / \mathbf{s})\end{array}$ & $\begin{array}{c}\text { Kedalaman } \\
(\mathbf{m})\end{array}$ & $\mathbf{p H}$ & $\begin{array}{c}\text { Salinitas } \\
(\mathbf{p p t})\end{array}$ & $\begin{array}{c}\text { Kecerahan } \\
(\mathbf{\%})\end{array}$ \\
\hline I & 28 & 0.07 & 3,1 & 7 & 30 & 100 \\
II & 29 & 0.08 & 2 & 7 & 29 & 100 \\
III & 29 & 0.13 & 1,5 & 7 & 29 & 100 \\
\hline
\end{tabular}

Tabel 6. Analisis tekstur substrat di Perairan Desa Langara Bajo

\begin{tabular}{ccccccc}
\hline \multirow{2}{*}{ Stasiun } & \multicolumn{5}{c}{ Partikel (\%) } & \multirow{2}{*}{ Kategori } \\
\cline { 2 - 6 } & Kerikil & $\begin{array}{c}\text { Pasir sangat } \\
\text { kasar }\end{array}$ & $\begin{array}{c}\text { Pasir } \\
\text { kasar }\end{array}$ & $\begin{array}{c}\text { Pasir } \\
\text { halus }\end{array}$ & Lempung & \\
\hline I & 2,68 & 19,57 & 28,84 & 50,7 & 2,18 & Pasir \\
II & 12,89 & 28,44 & 21,6 & 3475 & 2,28 & Pasir \\
III & 3,8 & 16,94 & 21,11 & 55,36 & 2,81 & Pasir \\
\hline
\end{tabular}

Derajat keasaman atau $\mathrm{pH}$ merupakan kadar asam dan basa di suatu perairan. Hasil penelitian mengenai $\mathrm{pH}$ pada Perairan Desa Langara Bajo diperoleh salinitas pada semua stasiun adalah 7 (Tabel 6) dimana $\mathrm{pH}$ ini tergolong netral. $\mathrm{pH}$ air laut memang

Salinitas merupakan konsentrasi ratarata seluruh garam yang terkandung dalam air laut. Nilai salinitas sangat berpengaruh terhadap kehidupan organisme di perairan. Hasil penelitian salinitas pada Perairan Desa Langara Bajo (Tabel 6) menunjukkan masih dalam batas toleransi terhadap perkembangbiakan makrozoobenthos. Hal ini diperkuat oleh pernyataan Mudjiman (1981) bahwa batas toleransi salinitas untuk perkembangbiakan makrozoobenthos khususnya bintang laut adalah berkisar 15-45 ppt.

Tipe substrat pada lokasi penelitian adalah pasir. Tipe substrat sangat mempengaruhi keberadaan hewan benthos terutama bintang laut. Bintang laut banyak ditemukan membenamkan diri dan hidup secara berkelompok. Selain itu jenis bintang laut biasanya ditemukan pada habitat tertentu sesuai preferensi habitat ekosistem contohnya jenis P.nodosus ditemukan pada ekosistem lamun, Achantaster plancii pada ekosistem terumbu karang. Hal ini sesuai pernyataan Susetiono (2007), bahwa bintang laut cenderung normal sehingga sangat baik untuk keberadaan organisme benthos. Hal ini sesuai pernyataan Santoso (1988), bahwa pH dengan kisaran 5-9 tidak mempengaruhi biota laut khususnya hewan benthos.

memiliki habitat yang spesifik baik itu padang lamun, terumbu karang maupun daerah tubir.

Bintang laut memiliki siklus hidup yang sangat erat kaitannya dengan ekosistem lamun. Bintang laut memanfaatkan padang lamun sebagai tempat untuk mencari makan, memijah serta sebagai tempat berlindung dari seragan predator. Bintang laut jenis P.nodosus menyukai habitat berpasir. Adapun jenis lamun yang menyukai substrat berpasir adalah jenis E.acoroides. Lamun ini tersebar luas dan tumbuh subur pada daerah dengan substrat berpasir. Hal ini sesuai pernyataan Takaen dan Azkab (2010), bahwa spesies Enhalus acoroides Thalassia hemprichii, dan Syringodium iseotifolium adalah spesies tumbuhan lamun yang tumbuh pada substrat pasir dan patahan karang mati, terbuka saat surut, jauh dari pantai dan selalu digenangi air.

Padang lamun merupakan suatu habitat yang sangat penting bagi suatu organisme (Vonk et al., 2010). Struktur umum tumbuhan lamun yang memiliki akar, batang dan daun. Berdasarkan penelitian yang telah dilakukan, 
ditemukan hanya satu jenis lamun yaitu jenis Enhalus acoroides dengan skala kerapatan pada stasiun I yaitu 589,7 tegakan $/ \mathrm{m}^{2}$ dimana lamunnya lebih rapat dibandingkan dengan stasiun II yaitu 340,3 tegakan $/ \mathrm{m}^{2}$. Sedangkan kerapatan lamun pada stasiun II lebih rapat dibandingkan dengan stasiun III yaitu 189,7 tegakan $/ \mathrm{m}^{2}$.

Lamun jenis E.acoroides yang merupakan tempat berlindung organisme dari hantaman gelombang secara langsung. Selain itu, dapat pula menjadi penstabil substrat, mengurangi kekeruhan air, serta menghalangi paparan sinar matahari. Daun lamun yang biasanya ditumbuhi alga epifit merupakan salah satu sumber makanan bagi bintang laut dan organisme lainnya (Moosleitner, 2004).

Penelitian yang dilakukan di Perairan Langara Bajo ditemukan hanya satu jenis lamun yaitu jenis E.acoroides. Lamun ini memiliki karakteristik daun berukuran panjang bisa mencapai 1 meter dan memiliki akar yang menyerupai rambut. Lamun jenis ini tumbuh subur pada daerah dengan substrat berpasir dan berarus tenang. Hal ini sesuai pernyataan Arifin dan Jompa (2005) bahwa lamun jenis E.acoroides dan Thalassia hemprichii hidup pada perairan yang relatif tenang dan substrat berpasir.

Kecepatan arus merupakan faktor yang sangat mempengaruhi pertumbuhan lamun, selain itu juga dapat mempengaruhi keberadaan makrozoobenthos. Berdasarkan penelitian yang telah dilakukan diperoleh kecepatan arus sebesar 0,07-0,13 m/s (Tabel 6) dimana ini masih tergolong arus lambat sehingga masih baik untuk keberlangsungan hidup organisme khususnya bintang laut. Hal ini diperkuat oleh pernyataan Ayyakkannu et al. (1991) bahwa makrozoobenthos menyukai jenis perairan yang berarus tenang yaitu sekitar $0,38-0,01 \mathrm{~m} / \mathrm{s}$. Sedangkan kecerahan berkaitan erat dengan proses fotosintesis oleh lamun yang terjadi di perairan. Selain itu juga berpengaruh terhadap keberadaan bintang laut di perairan. Jenis lamun E.acoroides yang merupakan jenis makanan yang paling banyak dikonsumsi oleh bintang laut. Dalam pertumbuhannya, lamun sangat membutuhkan cahaya untuk kelangsungan hidupnya. Berdasarkan pengamatan yang dilakukan di Perairan Desa Langara Bajo diperoleh kecerahan 100\% yang mana masih sangat baik untuk proses pertumbuhan lamun. Hal ini sesuai pernyataan Zimmerman (2006), bahwa lamun dapat berfotosintesis dengan baik pada tingkat kecerahan yaitu $10-37 \%$.

Kedalaman perairan juga merupakan salah satu faktor pendukung terjadinya proses fotosintesis oleh lamun. Kedalaman air di Perairan Desa Langara Bajo yaitu 1,5-3,1 m. Berdasarkan hasil pengamatan tersebut, diketahui bahwa kepadatan lamun yang ada di Perairan Langara Bajo masih sangat subur karena selain peraiannya yang tidak terlalu dalam, juga paparan sinar matahari masih masuk sampai ke dasar perairan. Hal ini sesuai pernyataan Ira (2011) bahwa kedalaman perairan sangat mempengaruhi proses fotosintesis pada lamun serta proses sedimentasi yang membawa makanan bagi organisme benthos.

Preferensi habitat masing-masing dari berbagai jenis bintang laut adalah tergantung pada kondisi substrat dan kemampuan suatu lingkungan untuk memenuhi kebutuhan hidupnya atau sumber makanan baginya. Hal ini sesuai pernyataan Scheibling (1980) bahwa tipe substrat yang tidak sesuai dengan kebutuhan pakan akan membatasi sebaran suatu spesies bintang laut di perairan.

\section{Simpulan}

Berdasarkan penelitian yang telah dilakukan di Perairan Desa Langara Bajo dapat disimpulkan bahwa :

1. Jenis bintang laut yang ditemukan di Perairan Desa Langara Bajo adalah P.nodosus, L.laevigata dan A.typicus. Dengan kepadatan berkisar antara 1,07 dan $2,00 \mathrm{ind} / \mathrm{m}^{2}$.

2. Jenis lamun yang ditemukan di Perairan Desa Langara Bajo adalah E.acoroides dengan kepadatan berkisar antara 189,7 dan 589,7 tegakan $/ \mathrm{m}^{2}$.

3. Jenis bintang laut P.nodosus banyak ditemukan di perairan yang tingkat kerapatan lamunnya tinggi, sedangkan jenis A.typicus ditemukan pada substrat berpasir yang jarang ditumbuhi lamun atau dominan substrat pasir.

\section{Daftar Pustaka}

Arifin dan Jompa, J. 2005. Studi Kondisi dan Potensi Ekosistem Padang Lamun sebagai Daerah Asuhan Biota Laut. Jurnal Ilmu Perairan dan Perikanan Indonesia. 12(2): 73-79.

Ayyakkannu, K., C. Raghunathan and T. Rajkumar, 1991. Socioeconomic 
profiles of fisherman communities from the Southeast coast of India. Journal Phuket Marine. Biological Center Special Publication. No. 9: 49-55.

Gaffar, S., Neviaty, P. Z. Dan Pradina, P. 2015. Preferensi Mikrohabitat Bintang Laut Perairan Pulau Hari, Sulawesi Tenggara. Jurnal Ilmu dan Tekhnologi Kelautan Tropis. 6(1). 1-15.

Hutabarat, S dan S. M. Evans. 1985. Pengantar Oseanografi. Universitas Indonesia. Press. Jakarta.

Ira. 2011. Keterkaitan Padang Lamun Sebagai Pemerangkap dan Penghasil Bahan Organik Dengan Struktur Komunitas Makrozoobenthos di Perairan Pulau Barrang Lompo. IPB. Bogor.

Khouw, A. S. 2008. Metode dan Analisa Kuantitatif dalam Bioteknologi Laut. Universitas Pattimura. Ambon.

Lee, T. Dan S. Shin. 2013. Echinoderms Fauna of Kosrae, the Federation States of Micronesia. J. Of Animal Systematics, 29(1):1-17.

Marsh J. A, Dennison, W. C. dan Alberte, R. C. 1986. Effect of Temperature on Photosyintesis and Respiration in Eelgrass (Zostera marina L.) Journal Exp Mar Biol Ecol. 101: 257-267.

Moosleitner. H. 2004. Observation of Asteroidea (Echinodermata) Arroun the Indonesian Island of Bali, Echinoderm: Munche. London. 245248.

Mudjiman, A. 1981. Budidaya Udang Windu. PT. Penebar Swadaya. Jakarta.

Odum, E. P. 1993. Fundamental of Ecology. Universitas Gajah Mada - Press. Jogjakarta.

Puspitasari, Suryanti dan Ruswahyuni. 2012. Studi Taksonomi Bintang Laut (Asteroidea, Echinodermata) Dari Kepulauan Karimunjawa. Jepara. Journal of Management of Aquatic Resources. 6(1).

Rompis, B. R., Marnix, L. D. L., Deidy. Y. K dan Adelfia. P. 2013. Diversitas Echinodermata di Meras Kecamatan Bunaken Sulawesi Utara. FMIPA. Universitas Sam Ratulangi. Manado.

Santoso, A., 1988. Komposisi Hewan Makrozoobentos pada Kali Banjir Kanal

Timur, Kali Banjir Kanal Barat Hilir dan Kali Banjir Kanal Barat Hulu di Kotamadya Semarang. Skripsi. Fakultas Peternakan Universitas Diponegoro. Semarang.

Scheibling, R.E. 1980. Dynamic and Feeding Activity of Hight-Density Aggregation of Oreaster reticulatus (Echinodermata : Asteroide) in Sand Patch Habitat. Marine Ecology Series 2. 321-327.

Sloan, N. A. 1980. Aspect of The Feeding Biology of Asteroids. Oseanografi. Marine Biology. Ann.

Soegianto. 1994. Ekologi Kuantitatif. Usaha Nasional. Jakarta.

Supono dan U, Y, Arbi, 2010. Struktur Komunitas Echinodermata di Padang Lamun Perairan Kema. Oseanologi dan Limnologi di Indonesia. ISSN 0125-9830.

Susetiono. 2007. Lamun dan Fauna di Teluk Kuta, Pulau Lombok. Pusat Penelitian Oseanografi-LIPI. Jakarta.

Takaendengan, K dan Azkab, M.H, 2010. Struktur Komunitas Lamun di Perairan Pulau Talise, Sulawesi Utara. Jurnal Oseanografi dan Limnologi-LIPI, Sulawesi Utara. Vol.36. No 1: 85-95.

Vonk JA, Christine MJ, dan Stapel J. 2010. Abundance Edge Effect, and Seasonality of Fauna in Mixed-Spesies Seagrass Meadows in Southeast Sulawesi. Indonesia. Mar. Biol. Res. 6 (3). 22-291.

Yumima, S. dan Jaida Idris. 2013. Studi kepadatan dan keanekaragaman jenis organisme bentos pada daerah padang lamun di perairan pantai kelurahan kastela kecamatan pulau ternate. Jurnal bioedukasi. 2(1). 154-162.

Zamani, N, P. 2015. Kondisi Terumbu Karang dan Asosiasinya dengan Bintang Laut (Linckia laevigatai) di Perairan Pulau Tunda, Kabupaten Seram, Provinsi Banten. Jurnal Teknologi Perikanan dan Kelautan. 6(1): 1-10.

Zimmerman RC, Smith RD, Alberte RS. 1987. Is growth of the Eelgrass nitrogen

limited a numerical simulation of effect of light and nitrogen on the growth dynamics of Zostera marina. Marine Ecology Progress Series 41:167-176. 